ИЗВЕСТИЯ АКАДЕМИИ НАУК ЭСТОНСКОИ ССР. ТОМ ХVII ХИМИЯ - ГЕОЛОГИЯ. 1969, Nㅡ 3

\title{
АЛКИЛИРОВАНИЕ АЦЕТОНА ЧЕТВЕРТИЧНЫМИ АММОНИЕВЫМИ СОЛЯМИ, СОДЕРЖАЩИМИ ТЕРПЕНОИДНЫЕ РАДИКАЛЫ
}

\begin{abstract}
Ранее нами описан способ получения геранил- и фарнезилацетона, а также метилrefiтенона алкилированием ацетоуксусного эфира соответственно хлористым геранил-, фарнезил- и пренилдиметилфениламмонием $\left[{ }^{1,2}\right]$. Последние соединения были получены действием диметиланилина на соответствующие фракцин теломера изопрена с его гидрохлоридами [ $\left.{ }^{3}\right]$.

В настоящей работе исследовалась возможность алкилирования ацетона терпеноидными четвертичными аммониевыми солями для осуществления непосредственного синтеза терпеноидных кетонов.

Хотя в литературе известны обменные реакции некоторых типов четвертичных аммониевых солей со спиртами $\left[{ }^{4}\right]$, сложными $\left[{ }^{5}\right]$ и простыми $\left[{ }^{6}\right]$ эфирами, а также с сернистыми $\left[{ }^{7}\right]$ и азотистыми $\left[{ }^{8}\right]$ соединениямн, до сих пор остаются не описанными их реакции с кетонами, приводящие к образованию продуктов С-алкилирования кетонов. Поэтому выяснение возможностей осуществления такой реакции представляет также и большой теоретический интерес.
\end{abstract}

Первоначальными опытами было выяснено, что при взаимодействии хлористого пренилдиметилфениламмония с ацетоном не происходит заметной реакции даже при длительном нагревании при температуре кипения ацетона. В автоклаве при температуре термического расщепления четвертичных аммониевых солей данного типа $\left(110^{\circ} \mathrm{C}\right)\left[^{3}\right]$ был получен продукт, не содержащий метилгептенона. Мы испытали также взаимодействие изобутилата пренилдиметилфениламмония с ацетоном, но оказалось, что реакция в этих условиях ведет к получению пренилизобутилового эфира. Известно $\left[{ }^{9}\right]$, что карбонильные соединения в присутствии сильных оснований способны частично отщеплять протон от метиловой группы, находящейся в $\alpha$-положении, что приводит к образованию енолят аниона. По такому механизму протекают, например, альдольные реакции, а также алкилирование высокозамещенных кетонов по способу Халлера-Бауэра. Это навело нас на мысль испытать взаимодействие хлористого пренилдиметилфениламмония с ацетоном в присутствии едкого кали, чтобы выяснить, может ли образовавшийся карбанион выступить в качестве нуклеофильного агента.

Оказалось, что в этих условиях реакция действительно проходит в желаемом направлении и ведет к получению метилгептенона: 
диацетоновый спирт, а также- ряд продуктов конденсаций, кипящих выше метилгептенона.

Разработанные на хлористом пренилдиметилфениламмонии оптимальные условия реакции были применены к четвертичным аммониевым солям, содержащим радикалы высших гомологов пренилхлорида, - к хлористому геранил- и фарнезилдиметнлфениламмонию. Было обнаружено, что и с этими соединениями реакции проходят в желаемом направлении и приводят к образованию соответственно геранил- и фарнезилацетона. Однако необходимо отметить, что в обоих случаях на блюдалось образование еще большего количества побочных продуктов, чем в случае метилгептенона. При вакуумной перегонке сырого продукта реакции хлористого геранилдиметилфениламмония с ацетоном была выделена фракция геранилацетона, ссдержащая $78 \%$ целевого продукта. Из хлористого фарнезилдиметилфениламмония была получена фракция фарнезилацетона с содержанием $53 \%$ целевого продукта.

В итоге можно заключить, что разработанным способом геранил- и фарнезилацетон получаются значительно более загрязненными побочными продуктами кетонного характера, чем по описанному нами ранее способу $\left[{ }^{2}\right]$.

\section{ЭКСПЕРИМЕНТАЛЬНАЯ ЧАСТЬ}

Исходные четвертичные соли - хлористые пренил-, геранил- и фарнезилдиметилфениламмоний - получили по ранее описанным методикам $\left[{ }^{3}\right]$.

\section{1. Алкилирование ацетона хлористым пренилдиметил- фениламмонием}

а. При температуре термического разложения четвертичной аммониевой соли

Хлористый пренилдиметилфениламмоний растворяется в ацетоне. Соответствующие каждому опыту количества ацетона и щелочного агента приведены в таблице.

Суспензию загрузили в лабораторный автоклав (емкостью $250 \mathrm{M}$, из нержавеющей стали, снабженный вращательным и нагревающими устройствами) и добавили безводную щелочь. Для лучшего перемешивания в автоклав загрузили стеклянные шарики, затем автоклав закрыли и нагревали при вращении в течение определенного времени $(2-3$ ч). После охлаждения автоклав разгрузили, осадок отфильтровали промыванием небольшим количеством ацетона. Затем отогнали избыток ацетона. Остаток влили в охлажденный $5 \%$-ный раствор $\mathrm{HCl}$ (чтобы удалить диметиланилин) и перемешивали 5 мин. Органический слой отделили, а водный несколько раз экстрагировали эфиром, эфирную вытяжку соединили с органическим слоем, промыли до нейтральной реакции и высушили над $\mathrm{MgSO}_{4}$. Эфир отогнали и остаток перегнали в вакууме. Были получены три фракпии: 1) т. кип. $35-60^{\circ}$ (15 мм), 2) т. кип. $60-75^{\circ}\left(15\right.$ мм), 3) т. кип. $75-105^{\circ}(15$ мм). Во всех фрак. циях определили содержание метилгептенона газохроматографическим методом, используя в качестве эталона образец метилгептенона, синтезированный известным в литературе способом $\left[{ }^{12}\right]$, исходя из изопрена.

б. При температуре кипения ацетона

В круглодонную трехгорлую колбу, снабженную обратным холо- 
дильником и механической мешалкой, загрузили 25,8 г хлористого пренилдиметилфениламмония и 80 г ацетона, затем перемешивали некоторое время при температуре $35^{\circ}$, чтобы дать четвертичной аммониевой соли раствориться (большая часть четвертичной аммониевой соли не растворилась). Затем добавили 6 г КОН, температуру подняли до кипения ацетона и реакционную смесь перемешивали при этой температуре 5 ч. После охлаждения смеси осадок отфильтровали и ацетон отогнали. Метилгептенон выделили по методике, аналогичной описанной в предыдущем пункте.

\section{2. Получение геранилацетона}

Для получения геранилацетона провели два опыта по методикам 1 а и 16 , аналогичным примененным при получении метилгептенона.

По методике 1а из 14,7 г хлористого геранилдиметилфениламмония, 5 г КОН и 10 г ацетона было получено нагреванием при $110^{\circ}$ в автоклаве 2,7 г фракции геранилацетона с т. кип. $85-100^{\circ}(2$ мм), в которой содержалось $78 \%$ геранилацетона. Выход геранилацетона 2,1 г $(31 \%)$.

По методике 16 из 14,7 г хлористого геранилдиметилфениламмония, 3 г КОН и 50 г ацетона получено 2,95 г фракции геранилацетона с т. кип. $85-105^{\circ}$ (3 мм). Выход геранилацетона 1,95 г (29\%).

\section{3. Получение фарнезилацетона}

Из 18,1 г хлористого фарнезилдиметилфениламмония (с содержанием $\mathrm{Cl} 5,80 \%$ ), 50 г ацетона и 4 г $\mathrm{KOH}$ было получено по методике 1а 3,2 г фракции фарнезилацетона с т. киг. $115-129^{\circ}(1$ м. $)$, в которой, по данным анализа, содержалось $53 \%$ фарнезилацетона. Выход фарнезилацетона 1,7 г $(21 \%)$.

\section{4. Методика газохроматографического анализа}

Анализы были проведены на газовом хроматографе «Хром-1» произеодства фирмы «Лабораторне Пристрое» ЧССР. Применяли колонки, заполненные полиэтиленгликолем 4000, нанесенным в количестве $5 \%$ на твердый адсорбент хромосорб $W$. Для анализа фракций метилгептенона и геранилацетона применялась колонка длиной 7 м, а для фарнезнлацетона - 2,5 м. В качестве газа-носителя применялся аргон, подаваемый со скоростью 10 мл/мин. Количество пробы 0,1 мкл. Рабочая температура при анализе метилгептенона $110^{\circ}$, геранилацетона $160^{\circ}$ и фарнезилацетона $180^{\circ}$.

\section{Выводы}

1. Впервые изучена реакция алкилирования ацетона четвертичными аммониевыми солями, содержащими терпеноидные радикалы аллильного типа.

2. Найдено, что реакция происходит под каталитическим влиянием едких щелочей.

3. Разработан новый способ получения метилгептенона, геранили фарнезилацетона.

4. Обнаружено, что реакция сопровождается образованием ряда побочных продуктов. 
Л И Т Е Р А У Р А

1. Л ээтс К. В., К огерман А. П., Авт. свид. СССР, № 184267, 1966; Бюлл. изобр., № 15 (1966).

2. Л ээтс К. В., Когер ман А. П., Изв. АН ЭССР, Хим. Геол., 18, № 1, 33 (1969).

3. Л ээт с К. В., ЖОХ, 31, 1869 (1961).

4. Сеткина В. Н., Курсанов Д. Н., Изв. АН СССР, ОХН, № 2, 228 (1948).

5. К у р санов Д. Н., С еткин а В. Н., Изв. АН СССР, ОХН, № 3, 274 (1949),

6. К у р санов Д. Н., С еткин а В. Н., Докл. АН СССР, 65, 847 (1949),

7. S n y der H., S p e ck R., J. Am. Chem. Soc., 61, 2895 (1939).

8. R o d i o n o v V. M., Bull. Soc. chim. France, 39, 305 (1926).

9. Беккер В. К., Введение в электронную теорию органических реакций, М., «Мир», 1965 , c. 284.

10. Амер. пат. 1550792; СА, 20, 51 (1926).

11. Чехосл. пат. 85207 (1955); СА, 50, 1078 (1956).

12. Чехосл. пат. 112243 (1964); СА, 62, 13049 (1965).

Ннститут химии

Академии наук Эстонской ССР
Поступила в редакцию $31 / \mathrm{X} \quad 1968$

\section{K. LAATS, AVO KOGERMAN}

\section{ATSETOONI ALKOOLIMINE TERPENOIDSEID RADIKAALE SISALDAVATE KVATERNAARSETE AMMOONIUMSOOLADEGA}

Uuriti atsetooni C-alküülimisvõimalust kvaternaarsete ammooniumsoolade prenüülgeranüül- ja farnesüüldimetüülfenüülammooniumkloriididega. Leiti, et reaktsioon toimuל sööbeleeliste juuresolekul ja et tekkivate terpenoidsete ketoonide saagis ei muutu oluliselt temperatuurivahemikus $56-115^{\circ} \mathrm{C}$. Paralleelselt põhiproduktiga tekib mitmeid kōrvalprodukte.

\section{K. LAATSS, AVO KOGERMAN}

\section{ALKYLATION OF ACETONE WITH QUATERNARY AMMONIUM SALTS CONTAINING TERPENOIC RADICALS}

C-alkylation of acetone with prenyl-, geranyl- and farnesyl-dimethyl ammonium chlorides have been studied. It has been found that the reaction occurs in the presence of caustic alkalis as catalysts. The yields of terpenoic ketones are similar in the temperature range from $56^{\circ}$ to $115^{\circ} \mathrm{C}$. The reaction is accompanied by the formation of a number of by-products. 